\title{
Timing: the Achilles heel of forensic pathology
}

\author{
Roger W. Byard ${ }^{1}$
}

Accepted: 17 June 2016/Published online: 5 July 2016

(C) Springer Science+Business Media New York 2016

"Time is an illusion"

Albert Einstein (1879-1955)

A frequent scenario in the courtroom involves a persistent lawyer trying to lock a pathologist into a particular time frame for a finding, event, or injury. In cases of trauma, a common gambit involves a question as to whether the described injuries were recent or old. These terms are then asked to be defined and specific time frames are advanced: "if you assert that the injuries were recent, could that be $3 \mathrm{~h}$ ?" If that is agreed to, then the cascade of follow up questions often includes "well would you be able to exclude them being $2.5 \mathrm{~h}$ old?", "or perhaps $2 \mathrm{~h}$ ?", "or even $1.45 \mathrm{~h}$ of age?", "is it even possible that the injuries were only an hour old?", and so on. Those with less experience in court may attempt to assist by being as 'precise' as possible in their answers to the questions which are designed to prove or disprove the possibility of a suspect being present at the time of a crime. This may result in the expert being boxed into an artificial time frame resulting in a concluding statement by the interrogating lawyer along these lines: "as the accused was the only individual present with the victim within the time frame advanced by the examining pathologist then he/she must have been responsible for the assault."

The reality is that biological processes are a continuum and cannot be compartmentalized into precisely defined

Roger W. Byard

roger.byard@sa.gov.au

1 Discipline of Anatomy and Pathology, School of Medicine, The University of Adelaide, Level 3 Medical School North Building, Frome Road, Adelaide 5005, Australia time periods. This, then, is our "Achilles heel" which has been defined (perhaps optimistically in some cases) as an area of weakness despite overall strength; i.e., while we usually have an excellent understanding of the general principles and sequence of responses to injury, disease, and pathological processes, it may simply not be possible to use this to determine the exact timing for an individual case. There are a myriad of reasons for this that include idiosyncratic responses to injury and to pathophysiological processes, the wide variation that exists in the types, force/patterns of trauma, and significant differences that occur in ante and post-mortem environments. It is clearly illogical to assume that every injury and every process in every person would follow identical time lines.

The timing of death is a classic example of how well a process is understood and yet how poorly this can be applied to specific cases. It has been recognized for centuries that after death a series of stereotypical changes occur that commence with cooling of the body (algor mortis), stiffening of muscle groups (rigor mortis), and pooling of blood in dependent parts (livor mortis) [1-3]. This is followed by autolysis, putrefaction, and skeletonization, sometimes with additional processes such as adipocere formation [4]. Despite apparently precise scientific methods to date post-mortem interval being developed that are based on comparisons between core body and environmental temperatures [5], it is well recognized that these are frequently confounded by variation in body size and fat content, the wetness of the body, the amount of clothing or bedding, changes in the ambient temperature, disturbance of the scene, and the presence of strong air currents/winds. Post-mortem changes such as putrefaction and skeletonization also cannot be relied upon to indicate consistent time frames as they may be greatly accelerated by 
environmental factors such as high ambient temperatures, or by endogenous infectious or metabolic conditions [6, 7].

Another post-mortem change that may be encountered is the development of adipocere or corpse wax in bodies exposed to certain environmental conditions when triglycerides have hydrolyzed into free fatty acids and glycerin [8]. Although it is thought to take months or years to develop, it may occasionally occur within days of death, again emphasizing the marked temporal variability that characterizes biological processes $[9,10]$.

In some jurisdictions the contemporaneous deaths of two elderly spouses in a vehicle accident may raise the question as to who died first. This, of course, may have great significance in terms of inheritance if there are family members from previous marriages who may be only considered in the will of one of the decedents and not the other. However, reports giving estimates on the timing of the deaths based on relative ages and injuries are often only guesswork with no scientific basis, particularly if the ages of the decedents and the types of injuries are comparable.

Similar difficulties may occur in attempting to date vital processes that have occurred before death. The aging of bruises is an excellent example of problems that may occur in attempting to impose a rigid temporal framework on a quite fluid biological phenomenon. It is well recognized that the time taken for a bruise to appear may be markedly affected by the location of the injury and the depth of the bleeding. Charts giving precise timing for color changes listed in textbooks have been shown to be contradictory and non-reproducible and the rates and nature of histological changes can vary greatly depending on the site of tissue sampling [11, 12].

The time taken for the stomach to empty has been used on occasion in court in an attempt to give some idea of the time between a last meal and death [13]. However, for a number of decades it has been recognized that individual variability makes this a very imprecise indicator. In fact, Marshall nearly half a century ago commented that "the rate of emptying of the stomach is so variable that it cannot be used to give any certain indication of the time that has elapsed between the last meal and death" [14]. The problem is that the rate of gastric emptying may be significantly affected by the nature of the ingested food, stress, drugs, disease states, and infections [13]. Thus, if food is found within the stomach at autopsy by a pathologist, the most reasonable conclusion is that the person has died sometime after eating.

Unfortunately these concepts are often difficult to translate for the courts. For example, despite an expert giving quite a detailed dissertation explaining why the dating of bruises is at best imprecise, the next question is often one asking for the precise age of a specific lesion. This is partly due to a failure to understand the gray areas of pathology that in previous decades may have been underemphasized. Also it may not suit a particular legal argument to have an open ended time period. Whatever the reasons for this medicolegal mismatch, it is important that pathologists are very aware of the considerable limitations that the autopsy examination of devitalized organs may have in terms of shedding light on the exact timing of particular ante and post-mortem events/processes. Determining whether time itself is an illusion or not is a little beyond the scope of this editorial, however, the belief that pathological analyses can always provide an accurate chronology for an autopsy finding probably is.

\section{References}

1. Casper JL. A Handbook of the practice of forensic medicine based upon personal experience. Vol 1. Thanatological Division. Ch 2. London: The New Sydenham Society; 1861. p. 14-55.

2. Madea B. Methods for determining time of death. Forensic Sci Med Pathol. 2016. doi:10.1007/s12024-016-9776-y.

3. Madea B. Estimation of the time since death. 3rd ed. Boca Raton: CRC Press; 2016.

4. Prahlow J, Byard RW. An atlas of forensic pathology. New York: Springer; 2012.

5. Henssge C, Madea B. Estimation of the time since death in the early post-mortem period. Forensic Sci Int. 2004;144:167-75.

6. Zhou C, Byard RW. Factors and processes causing accelerated decomposition in human cadavers. An overview. J Forensic Leg Med. 2011;18:6-9.

7. Byard RW. The complex spectrum of forensic issues arising from obesity. Forensic Sci Med Pathol. 2012;8:402-13.

8. Byard RW. Adipocere-the fat of graveyards. Am J Forensic Med Pathol. 2016. doi:10.1097/PAF.0000000000000251.

9. Thali MJ, Lux B, Lösch S, Rösing FW, Hürliman J, Feer P, et al. "Brienzi" - the blue vivianite man from Switzerland: time since death estimation of an adipocere body. Forensic Sci Int. 2011;211:34-40.

10. Kumar TSM, Monteiro FN, Bhagavath P, Bakkannavar SM. Early adipocere formation: a case report and review of literature. J Forensic Leg Med. 2009;16:475-7.

11. Byard RW, Wick R, Gilbert JD, Donald T. Histologic dating of bruises in moribund infants and young children. Forensic Sci Med Pathol. 2008;4:187-92.

12. Byard RW, Langlois NEI. Bruises - is it a case of "the more we know the less we understand"? Forensic Sci Med Pathol. 2015;11:479-81.

13. Horowitz M, Pounder DJ. Gastric emptying-forensic implications of current concepts. Med Sci Law. 1985;25:201-14.

14. Marshall TK. Changes after death. In: Camps F, Robinson AE, Lucas BGB, editors. Gradwohl's Legal Medicine. 2nd ed. Bristol: John Wright \& Sons Ltd; 1968. p. 105. 